\title{
ATG7 wt Allele
}

National Cancer Institute

\section{Source}

National Cancer Institute. ATG7 wt Allele. NCI Thesaurus. Code C120966.

Human AT G7 wild-type allele is located in the vicinity of 3p25.3 and is approximately 285

$\mathrm{kb}$ in length. This allele, which encodes ubiquitin-like modifier-activating enzyme AT G7

protein, is involved in the regulation of autophagy. 